\title{
Diaspora Engagement Strategies and Policies
}

\author{
UDK: $314.151 .1(045)$ \\ Jovan Filipovic \\ University of Belgrade, Faculty of Organizational Sciences, Serbia \\ jovanf@fon.rs \\ Srečko Devjak \\ University of Ljubljana, Faculty of Administration, Slovenia \\ srecko.devjak@fu.uni-lj.si \\ Bogomil Ferfila \\ University of Ljubljana, Faculty of Social Sciences, Slovenia \\ bogomilferfila@hotmail.com
}

\section{ABSTRACT}

Diasporas have been making contributions to their motherland for a long time (Ionescu, 2006), without waiting for policies to rally them and, if truth be told, very often finding them to be the major obstacles for establishing the partnership. However, diaspora-motherland partnership is closely related to institutional frameworks, socio-economic settings, political milieu as well as issues of perceptions, images, trust and social identification, in both the home and host country, most of which are within the scope of public administration. Moreover, the evolution of policy awareness and a thorough understanding of the diaspora and development nexus are, in some countries, the result of the efforts of public administration.

The development of diaspora strategies is essential because it demonstrates how state agencies, policy makers and individual citizens themselves have begun to think beyond national borders and make efforts to build non-territorial forms of organisation, such as Diaspora Virtual University. Promotion of networks, strategic alliances and sustained institutional cooperation between diaspora and the policy makers such as the Ministries for Diaspora, as well as other officials dealing with diaspora and development related issues have become the subject of primary interest in many countries, one of them being Serbia.

As a part of the effort to formulate effective and just policies used to respond to the brain drain, the paper analyses and recommends different policy types. Among different models of academic diaspora congregation is, no doubt, the alumni model, which proved to be very useful for both, developed and developing countries. The paper presents the concept as a part of the "brain gain« model and states the principles distilled from the alumni concept

Filipovic, J., Devjak, S. \& Ferfila, B. (2012).

Diaspora Engagement Strategies and Policies. Uprava/Administration X(2), 7-26. 
experience, which summarize the current wisdom regarding development of a community which will serve as the sintelligence pool» for Diaspora Virtual University.

Different types of remittances, as well as pessimistic and optimistic perspectives on remittances, are analyzed in the paper, and recommendations are summarized for current and future policy makers. Recognizing diaspora as a valuable foreign investor a model of partnership through the Serbian Regional Chambers of Commerce is also proposed.

Key words: diaspora engagement policies, brain drain, brain gain, remittances, alumni model, diaspora investments

JEL:D78, F22, F24, J68,038

\section{Introduction}

Diasporas have been making contributions to their motherlands for a long time (Ionescu, 2006), without waiting for policies to rally them and, if truth be told, very often finding them to be the major obstacles for establishing the partnership. However, diaspora-motherland partnership is closely related to institutional frameworks, socio-economic settings, political milieu as well as issues of perceptions, images, trust and social identification, in both the home and host country, most of which are within the scope of public administration. Moreover, the evolution of policy awareness and a thorough understanding of diaspora and development nexus are, in some countries, the result of the efforts of public administration.

In order to maximize the benefits of the potential diaspora-motherland partnership and assure that diasporas are not deprived of the ownership of their contributions, the policies that are increasingly developed in many countries to tap, flock and mobilize diaspora, should be realistic, well thought, fair and feasible (Ionescu, 2006). In diaspora lies precious intellectual, social and financial capital that sending countries must seek and nurture through networks and alliances (»brain chains«). Mobilisation of this latent »national« resource, as Gamlen (2006) calls it, through such connectivity programs do not require a large infrastructural investment, which is the advantage of any diaspora option. Here, diaspora option refers to one of the two brain gain alternatives. As Meyer \& Brown (1999) state, brain gain can be achieved either through diaspora homecoming initiatives (return option) or through their remote mobilization and commitment to development of the home country (diaspora option). Assumption that many expatriates are not likely to return, at least in the short term, is the bases for significant number of diaspora policies.

The development of diaspora strategies is essential because it demonstrates how state agencies, policy makers and individual citizens themselves have begun to think beyond national borders and make efforts to build non- 
territorial forms of organisation, such as Diaspora Virtual University (Filipovic \& Putnik, 2009). Promotion of networks, strategic alliances and sustained institutional cooperation between the diaspora and the policy makers such as the Ministries for Diaspora, as well as other officials dealing with diaspora and development related issues have become the subject of primary interest in many countries, one of them being Serbia.

The role of the government, contrary to the actions of many administrations, including Serbian, should not be to manage their diasporas, but to promote public policy making which is sensitive to the needs and aspiration of the members of diaspora and their counterparts in the motherland, nurture ties with and within diaspora and, especially establish managerial practices directed at creating appropriate environment and providing necessary resources (enabling conditions) for the promotion of diaspora-motherland partnership.

Discussing the fairness of the policy-making process, Kunreuther (1980) emphasizes the negative long-term consequence of forcing decisions of the stakeholder with the greatest power upon the weaker stakeholders. As he says "this is likely to be counterproductive since ,politically', exclusion may breed anger as well as ignorance", not to mention the "loss" of the potential for reaching just and practical solutions. Fischhoff et al. (1981) offer a comprehensive and well-phrased statement of the importance to involve all the interested parties and stakeholders of a particular policy: "Citizens in a democratic society will eventually interfere with decisions in which they do not feel represented. When lay people do force their way into hazard decisions, the vehemence and technical naivety of their response may leave the paid professionals abash, reinforcing suspicions about the stupidity of the public'. By avoiding these conflicts, early public involvement may lead to decisions that take longer to make, but are more likely to stick." Of similar opinion is The National Consumer Council (2004b, p. 7), which elaborates the necessity of the involvement of all the relevant parties: »In a world of increased pluralism, individualism and diversity of needs, it is increasingly difficult to know what users of services want. What is required above all is the active involvement of individuals in the determination of their own needs. ... When users are empowered, services become more responsive to rising expectations and demands."

\section{Policy Arena}

Governments' actions concerning diaspora issue are most often hasty and clumsy. Consequently, more often than not, things related to diaspora in many countries, for example in Serbia, happen in spite of government policy, rather than because of it. Recently, a large number of strategies, policies, programmes and actions has been proposed and developed to improve partnership between motherlands and their diasporas. 
In an attempt to come up with a »widely conceived and morally grounded strategy", as well as an "overarching policy and associated practices that facilitate the ongoing development of the relationship between (motherland) and its diaspora" (Boyle \& Kitchin, 2008, p. 6), we first need to clarify the meaning of strategies, policies, public policies in particular, and practices.

A strategy is a plan to do things a certain way to achieve a desired outcome, while a policy is a rule designed to ensure consistency in governance and to avoid undesirable outcomes. Policy should be a relatively stable, purposive course of action, followed by an actor or actors, in dealing with a problem or matter of concern such as, for example, diaspora engagement. On the other hand, like in the case of diaspora, strategies are seen as overarching frameworks which provide a certain level of coherence to the range of diaspora policies developed and implemented by various organizations.

Having examined numerous countries and their skilled diaspora approaches, we believe that countries which want to prosper need to embrace the following essential strategies to reduce their brain drain and advance the brain gain: (i) Promoting retention by providing incentives, (ii) Facilitating favorable conditions for returnees, (iii) Establishing a comprehensive and reliable database on the expert diaspora, (iv) Improving information provision to the diaspora, (v) Strengthening temporary engagement of the intellectual diaspora, (vi) Developing intellectual diaspora networks, (vii) Mobilizing the intellectual diaspora through Diaspora Virtual University (DVU), (viii) Establishing and improving mechanisms for remittances and investments, (ix) Tayloring a just and sound national diaspora policy, ( $x$ ) Increasing commitment of the government, (xi) Establishing governmental diaspora office (Ministry), and (xii) Promoting international organizations participation (Woldetensae, 2007, p. 4).

Public policy, as defined by Kilpatrick (Kilpatrick, 2000) is a system of »courses of action, regulatory measures, laws, and funding priorities concerning a given topic promulgated by a governmental entity or its representatives." It may be viewed as a political systems response to impetuses originating in its environment that might include both the motherland and the diaspora. Experts in diaspora should use their expertise not only in their respective fields of research and in academia, but as an input for policy makers, as well as shaping of political opinion. Through its Council, DVU makes efforts to optimize the interaction among policy, society and science, in terms of the development, usage and application of knowledge. As such, DVU serves as an »independent knowledge intermediary and as a unifying link between the policy arena and the knowledge arena« which significantly contributes to »a sustainable society where knowledge development and knowledge usage optimally meet the needs of society« (de Wit, 2004, p. 10).

The five stages of the policy cycle are: (i) Agenda-setting, which involves problem recognition, (ii) Policy Formulation, which deals with proposal of 
solution, (iii) Decision-making, which involves choice of solution, (iv) Policy Implementation, which deals with putting solution into effect and (v) Policy Evaluation, which involves monitoring the results.

\section{Agenda-setting model}

The first stage in policy process is agenda setting (Kingdon, 1995). According to Dearing \& Rogers (1996, p. 22) »The agenda setting process is an ongoing competition among issue proponents to gain the attention of media professionals, the public, and policy elites." It is a political, highly conflictive and competitive process, contingent on: (i) competing entries on policy agenda, (ii) ability to influence groups to action, (iii) positions and views of key policymakers, (iv) preferences of interest groups and (v) preferences of decision maker (Puentes-Markides, 2007, p. 2).

There is a plethora of possible policy problems that might grasp the attention of the potential stakeholders, including government, media and the public. In our case, such a problem is the neglected motherland-diaspora relationship, the condition that is the source of both dissatisfaction and generator of needs for which relief or redress by government action is sought.

The policy agenda is defined by Kingdon $(1995$, p. 3) as »a list of subjects or problems to which government officials, and people outside of government closely associated with those officials, are paying some serious attention at any given time ... the agenda setting process narrows [a] set of conceivable subjects to the set that actually becomes the focus of attention. " In general, there are two types of agendas; systemic or macro agendas and institutional or micro agendas. The first type pertains to the widest range of potential issues that might be nominated for consideration by the government, such as the motherland-diaspora relationship in its broadest sense. The second type includes those issues that are the elements of a larger framework, which is already under consideration by decision makers (Puentes-Markides, 2007). In the case of motherland-diaspora relationship, it might be concerned with some of the numerous particular problems, for example, how to facilitate provision of certain services by a given Ministry for Diaspora.

Upon decision to put an idea on the policy agenda, which is based on thorough survey and analysis of a large number of relevant factors, agenda setting goes through three streams: problem stream, proposal stream, and political stream. Problem stream refers to the process of convincing the policy decision makers to pay attention to one problem over others, thus increasing its chances to be put on and elevated on the agenda. Problem definition (frame and label), as well as the way it was announced are the factors that significantly influence this process. As a part of this process, diaspora members and supporters of sound diaspora policy need to engage in order to persuade the policy decision makers of the validity and the justifiability of their claims and induce the acceptance of their position. Proposal stream involves the process by which 
policy proposals are created, debated, reviewed, and adopted for serious consideration. It invokes the help of researchers, advisors and analysts, who need to contribute to shortlist the proposal. Among them, notably, are the experts in diaspora and other advocates of an appropriate diaspora policy. Political stream represents the collage of political will that is sometimes crucial for the fate of the agendas. This stream needs to be influenced by such factors as favorable national mood and public opinion towards diaspora, as well as to have inclination of influential interested parties.

As Kingdon (1995) claims, when these streams merge, a policy window opens, and stays open for only a short period of time. These situations require that problem is recognized, a solution is developed and presented to the policy community, a political situation is susceptible to policy change and constraints remain dormant. A chance of successful agenda setting considerably increases if all three constituents - problem, proposal, and politics - are optimized through an integrated process.

Following successful agenda setting, combined with policy formulation, decision-making, policy implementation and, subsequently evaluation, are performed, hopefully with participation of parties interested in existence and application of a just, smart and practical diaspora policy.

Countries that create the right policy and regulatory conditions to foster motherland - diaspora partnership, apart from being just and fair, аге also able to effectively and efficiently employ all kinds of diaspora capital and pace up transformation of innovative research into desired outcomes, considerably contributing to local communities and the improvement of the lives of its citizens, while often having positive regional and in some cases global impact.

A common point in any debate over innovation programmes in Serbia has been that current policies were tailored for a time in the Serbian science and research that no longer exists. The research institution landscape, the national science budget, relations within the triangle science-governmentsociety (industry), and especially the number and structure of highly talented and educated people, both in the motherland and in diaspora, has changed enormously over the last few decades to raise questions about the applicability of policies with roots in a long lost social economy.

\section{Diaspora engagement policies}

Gamlen (2006, p. 1) used his original typology to systematically review diaspora engagement policies of over 70 states. His typology arises from a twopronged argument: a) Diaspora engagement policies »consist of a diversity of measures« intended for »(re)producing citizen-sovereign relationships with expatriates", and b) »these measures can be coordinated as part of states' attempts to manage the scale of their political and economic maneuvers". 
Based on the assumption of the transnationalization of governmentality, Gamlen (2006, p. 5) identifies »three higher-level types of diaspora engagement policy« being:

- capacity building, to tactfully produce a »state-centric ,transnational national society'", and to develop a sset of corresponding state institutions",

- extending rights to the diaspora, thus being a factor that »benefits a legitimate sovereign«,

- extracting obligations from the diaspora, founded on the premise that diaspora members »owe loyalty to this legitimate sovereign«. Figure 1 summarizes the situation in different countries with respect to the three types of diaspora engagement policy.

Figure 1: Situation in different countries with respect to the three types of diaspora engagement policy

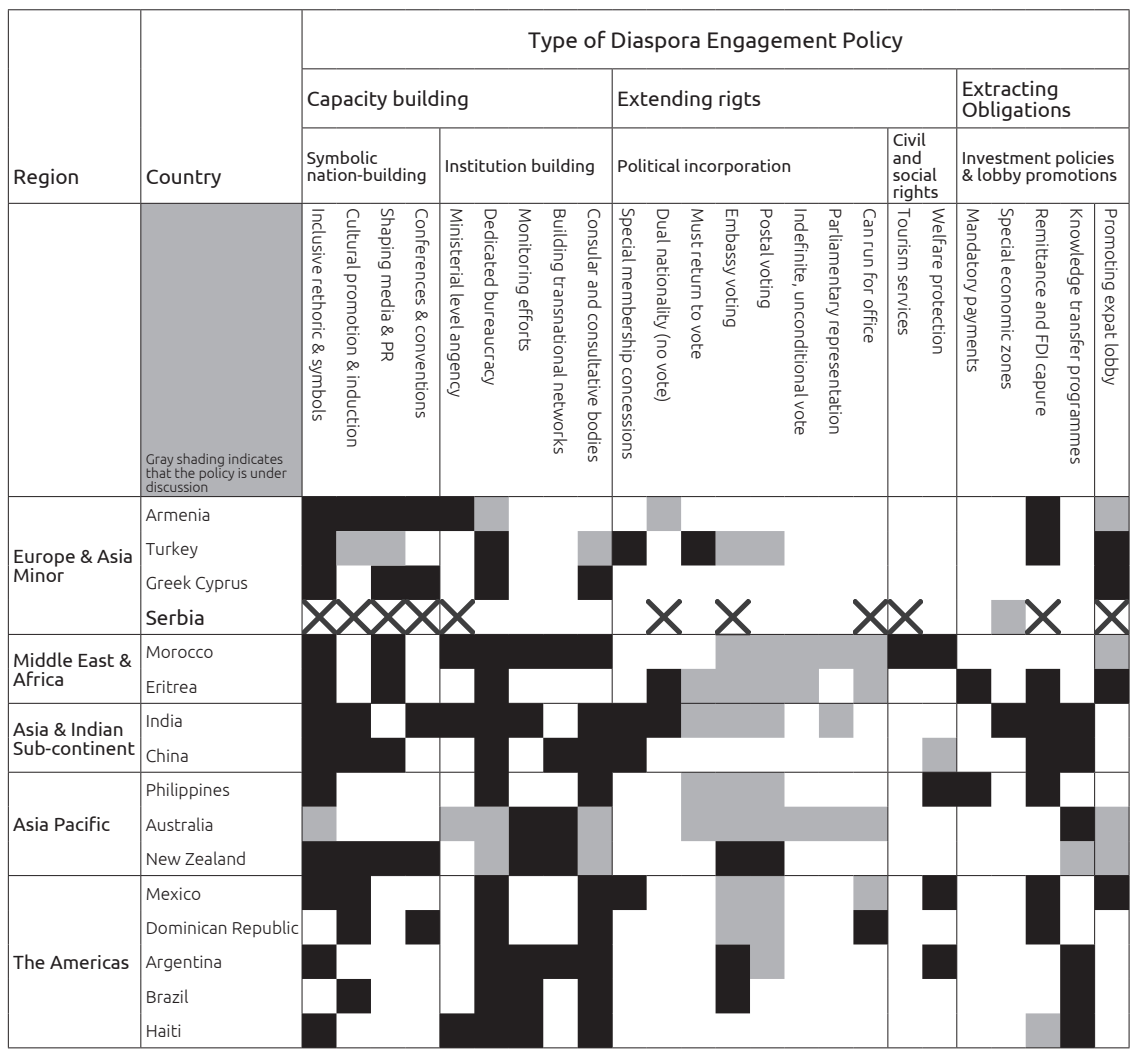

Source: Gamlen (2006); Serbia included by J. Filipovic

We included Serbia on the basis of the expertise with different types of diaspora engagement policy. Clearly, the situation in Serbia is not satisfactory. Although some elements of diaspora engagement policies do exist, they are often influenced by individuals and organizations that function in an 
environment complacent to the interests of certain political groups, who ensure their propagation in policy documents on a national level.

According to the levels of state involvement, as a part of its overall philosophy/ ethos, and corresponding diaspora ownership, Boyle et al. (2009) distinguish five different approaches of engagement with their diaspora (Figure 2):

1. Absent - low level of state engagement, with total diaspora ownership, formation of links between the motherland and the diaspora left to the market or to self-directed social, cultural and political movements, diaspora is self-organizing itself and the relationship with the motherland;

2. Custodian - the state fosters, acts as the guardian, regulates and polices existing and emerging diaspora networks. Slightly lower level of diaspora ownership;

3. Midwifery - the state identifies prospective engagements and potential champions/leaders and mobilizes and promotes them, with the ownership still staying firmly with the diaspora;

4. Husbandry - the state works in partnership with and facilitates existing diaspora organizations and networks in their activities, however with the diaspora ownership fading;

5. Demiurge (creator) - the state creates and controls diasporic initiatives and networks, with the intention, or not, of letting the market forces subsequently take over. Diaspora ownership is very small.

Figure 2: State approaches of engagement with their diaspora

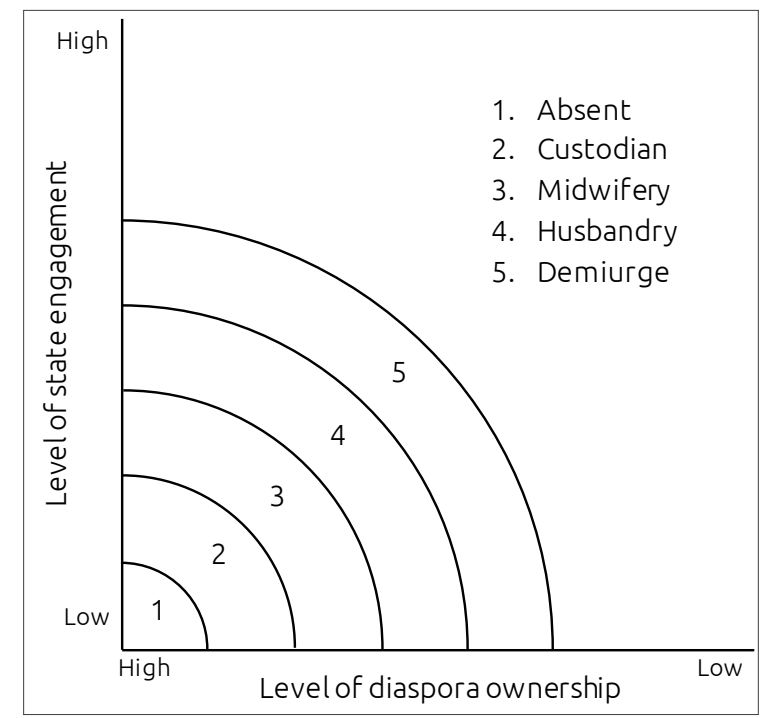




\subsection{Formulating a national diaspora policy}

Diaspora engagement is very often hindered by the lack of a sound and applicable policy. Specifically, many scholars and some policymakers believe that the current Serbian, so called model of diaspora-motherland cooperation, is totally inappropriate mechanism for today's complex, challenging, but rich in opportunities environment.

In order to successfully manage the processes of linking national development priorities and diaspora resources, it is important to establish an appropriate policy framework. A concrete, credible and transparent national policy and regulatory framework should be designed and communicated to support state efforts to build strong partnership with the diaspora. When tailoring a national diaspora policy, all relevant stakeholders, intellectual diaspora among them, other diaspora communities, local institutions, government policy makers, as well as concerned international development partners should be represented (Woldetensae, 2007).

Boyle et al. (2009) developed a checklist with five core and eight peripheral dimensions that could serve as a convenient tool for policy makers currently formulating and implementing diaspora policies. Even though policy makers could experiment along both, core dimensions are presumably less subject to change. The five core dimensions are:

- Rationale, which provides the overall approach to the development of diaspora policy,

- Definition, clearly defines the semantic scope of diaspora to include all relevant populations which constitute the nation's diaspora,

- Philosophy/Ethos lays out an overall philosophy for the nation's diaspora strategy and disseminates it among stakeholders,

- Overall Strategy, which specifies the policy mix and prioritize specific policy,

- Institutional Design/Architecture, develops the structures, programmes and technologies of delivery, best suited for the current motherlanddiaspora relationship constellation.

The peripheral dimensions include:

1. Culture building - Creating and fostering determination to bond with the motherland

2. Citizenship beyond the border - Enabling diaspora to exercise its rights and responsibilities.

3. Business network - Mutual fulfillment of motherland and diaspora economic interests

4. Information sharing - Developing and improving motherland-diaspora relationship 
5. (Philanthropy/remittances/Investments - Optimizing the potential of diaspora capital

6. Returnees - Easing diaspora passage to the motherland

7. (Affinity diaspora - Nurturing relations with those who established special affinity or affection for the nation state

8. Research capacity and knowledge - Expanding knowledge about diaspora, policy and acquiring best practice from elsewhere.

\subsection{Policies used to respond to the brain drain}

As Lowel (2001) states, some of the independent feedback loops, generated by highly skilled emigration, can be facilitated by policymakers. She identified the following policy typology:

- Return of migrants to their source country (migration)

- Restriction of international mobility (migration)

- Recruitment of international migrants (migration)

- Reparation for loss of human capital (monetary)

- Resourcing expatriates (diaspora options)

- Retention through educational sector policies and economic development (opportunities).

The so called migration policies, return, restriction, and recruitment, directly affect the movement of people. Monetary compensation to source countries for brain drain is the core of the reparation policy, while the resourcing expatriates, also known as diaspora option is the umbrella term for different approaches aimed to benefit from diaspora members. Retention policies are directed at lessening the incentives to emigrate, through improvements in the educational and economic sectors.

Through its activities and projects DVU will work towards outcomes that will contribute to the creation of a clearer picture of the number of experts from diaspora motivated to work on joint projects, as well as opportunities for partnerships on projects of mutual concern for the motherland and diaspora. Moreover, it is believed that these outcomes should include the potential to stimulate policy dialog at both national and European levels, as well as open the perspective for cooperation that will lead to a wise and just policy making and policy application processes.

Similar to the activities of the Brain Gain Malaysia (BGM, 2010) programme and its Diaspora Innovation Partnership (DIP) project, DVU will work to attract members of expert diaspora »with high-potential commercialization ready scientific / technological innovations « to either physically relocate to the motherland as technopreneurs or participate in all kinds of »distance techno-entrepreneurship « that will contribute to long-lasting partnership and benefit both sides. Through provision of a wide spectrum of incentives, DVU 
will initiate and enable commercialization of "promising research outcomes through proof of concept development, technology development and business development«.

\subsubsection{Alumni model}

Analyzing Armenia's diaspora, authors of the study state that among the sectors of modern society, the university sector has been probably the most successful in congregating its members, known as academic, scientific, intellectual or expert diaspora, and mobilizing their intellectual, social and financial capital to advance its mission (Mitra et al., 2007). Among different models of academic diaspora congregation is, no doubt, the alumni model, which proved to be very useful for both developed and developing countries. This model, based on "simple but strict requirements", has proven to be very instrumental in utilizing precious intellectual capital of academic diaspora. The model that was originally developed and perfected by elite American universities, has become an irreplaceable element of any »brain gain« programme. In essence, the alumni model has the craft of nurturing its dispersed alumni as the backbone, and can serve as the spring board from which many diaspora activities can be launched. Such activities include financial contributions, but most importantly, engagement of diaspora's intellectual and social capital for the benefit of the entire nation. Experience has shown that universities have to be very prudent in selecting and cultivating the core of the alumni organization, from where intellectual and financial leaders for the entire alumni community will emerge and who can be of vital importance for further alumni mobilization in endeavors such as Diaspora Virtual University (Filipovic \& Putnik, 2009).

The following principles, distilled from the alumni concept experience, summarize current wisdom regarding development of a community which will serve as the DVU »intelligence pool« (Mitra et al., 2007):

1. it is an exclusive community of over-achievers and the most valuable supporters

2. it is of vital importance to exclude the traditional type of diaspora leadership, encapsulated in the strict rule of the organization, which says that members had to bring status to the group rather than obtain it there

3. its membership consists of people who have similar level of accomplishments

4. it is a matter of prestige to be affiliated with the DVU

5. through dialogue among themselves and with other stakeholders, the members tend to acquire a better understanding of the motherland's actual needs, which helps them to tailor their contributions to the mission of the DVU. 


\subsection{Diaspora remittances and remittance policy}

According to Adebayo (2010, p. 16) remittances have long been seen as an important consequence of transnationalism, a »clear product of brain drain«, and one of the reasons that migration is tolerated, and very often encouraged. Although most people refer to remittances as the capital transfers in cash or in kind that a migrant makes to the country of origin which are, in fact, »monetary remittances", it can also refer to the so called »social remittances".

As Levitt (2001, pp. 54-60) states, there are three types of social remittances: (i) normative structure, (ii) systems of practice, and (iii) social capital. Normative structures include ideas, values and beliefs, systems of practice that are the actions created by normative structures and social capital that are the social networks and associated norms that have an effect on the productivity of a community. Combined by the entrepreneurial spirit and endeavors, monetary and social remittances contribute greatly to sustainable development of home countries. Some aspects of social remittances, like brain-gain, have been already analyzed and some, like social capital, will be treated further in the next chapters. In this section, we provide an overview of monetary remittances, necessary to comprehend their relation to social remittances, as well as the concept of Diaspora Virtual University.

Monetary remittances, as already stated, may be defined broadly as capital transfers in cash or in kind that a migrant makes to the country of origin. The World Bank estimates that in 2009 global remittances (around \$ 320 billion), from over 200 million migrants around the world (who make about 3 percent of the world's population), exceed as much as three times the overseas development assistance (ODA). Similar figures were reported by the UN's International Fund for Agricultural Development (IFAD). Remittances have grown faster than foreign direct investment (FDI) and official development aid in the past decade, doubling in several countries and rising by $10-15 \%$ per annum over 2001-05. In 2009, despite the economic crisis and contrary to the IMF estimates, remittances from Serbian diaspora grew 10\%, reaching \$5.5 billion, which is close to 15 percent of the GDP (Serbian Minister for Diaspora). At any rate, Serbia is in the top 11 remittance-receiving countries in the world (Petree \& Baruah, 2006).

The true value of remittances is considerably higher, since those data include only transfers through official channels, while large sums of money, as well as volumes of goods, remain unrecorded and transferred via informal channels. Moreover, in his analysis of the effect of remittances on Armenia' economy, Roberts (2004) concludes that the true amount of remittances is three times larger than officially reported. He further suggests that the insights gained on how remittance data are constructed might serve as guidance for other countries with significant diasporas. 
Table 1: Different types of remittances

\begin{tabular}{|c|c|c|}
\hline Type of remittance & Examples & $\begin{array}{l}\text { Recorded as } \\
\text { remittances }\end{array}$ \\
\hline $\begin{array}{l}\text { Money transfers through formal } \\
\text { banking system to individuals or } \\
\text { households in the motherland. }\end{array}$ & $\begin{array}{l}\text { Known as family remittances, used } \\
\text { mainly for basic consumption. }\end{array}$ & Recorded \\
\hline Community (collective) remittances & $\begin{array}{l}\text { Voluntary donations that organized } \\
\text { groups (hometown associations) } \\
\text { collect from their members to } \\
\text { finance community investments or } \\
\text { social events in their native towns. }\end{array}$ & Recorded \\
\hline $\begin{array}{l}\text { Donations by diaspora members } \\
\text { to institutions and organizations } \\
\text { operating in, or for the motherland. }\end{array}$ & $\begin{array}{l}\text { Donations are often collected } \\
\text { by the churches (humanitarian } \\
\text { organizations) in the host countries } \\
\text { and are held in bank accounts } \\
\text { there, to be transferred overseas } \\
\text { or used to settle international } \\
\text { payments on behalf of the church } \\
\text { (humanitarian organizations) in the } \\
\text { home country. }\end{array}$ & $\begin{array}{l}\text { Partially } \\
\text { recorded }\end{array}$ \\
\hline $\begin{array}{l}\text { Deposits made into bank accounts } \\
\text { held by the migrant overseas }\end{array}$ & $\begin{array}{l}\text { Diaspora members transfer money } \\
\text { to home countries as savings } \\
\text { deposits or for the purpose of } \\
\text { physical assets such as land, } \\
\text { housing, farm equipment and } \\
\text { supplies, inventories for small } \\
\text { businesses, and so on. }\end{array}$ & $\begin{array}{l}\text { Partially } \\
\text { recorded }\end{array}$ \\
\hline $\begin{array}{l}\text { Payments made by the migrant } \\
\text { on behalf of individuals in the } \\
\text { motherland }\end{array}$ & $\begin{array}{l}\text { Insurance premiums paid to } \\
\text { host country based companies, } \\
\text { educational and sophisticated } \\
\text { medical treatment expenses, } \\
\text { payments for international airfares } \\
\text { made directly to the airlines. }\end{array}$ & $\begin{array}{l}\text { Not } \\
\text { recorded }\end{array}$ \\
\hline $\begin{array}{l}\text { Money transferred informally in } \\
\text { cash or via an informal agent to } \\
\text { motherland }\end{array}$ & $\begin{array}{l}\text { Money sent trough friends and } \\
\text { relatives networks. }\end{array}$ & $\begin{array}{l}\text { Not } \\
\text { recorded }\end{array}$ \\
\hline Transfers in-kind to motherland & $\begin{array}{l}\text { Gifts, services, clothes and other } \\
\text { goods donated to churches and } \\
\text { humanitarian organizations. }\end{array}$ & $\begin{array}{l}\text { Not } \\
\text { recorded }\end{array}$ \\
\hline $\begin{array}{l}\text { Money that diaspora members } \\
\text { spend while in the motherland }\end{array}$ & $\begin{array}{l}\text { Money spent on local goods and } \\
\text { services (medical examinations and } \\
\text { treatments, spas, notaries, tourism, } \\
\text { child camps, pilgrimages). }\end{array}$ & $\begin{array}{l}\text { Partially } \\
\text { recorded }\end{array}$ \\
\hline $\begin{array}{l}\text { Money that diaspora members use } \\
\text { to pay taxes and duties }\end{array}$ & $\begin{array}{l}\text { Property taxes for what they own } \\
\text { in the motherland, custom duties, } \\
\text { highway tolls. }\end{array}$ & $\begin{array}{l}\text { Not } \\
\text { recorded as } \\
\text { remittances }\end{array}$ \\
\hline
\end{tabular}

Source: Modified table of Connell \& Brown (2004, online)

Remittances account for all the money earned by diaspora members that is spent in, or for the motherland, and may be classified as remittances for the family essential needs, home construction and for entrepreneurial endeavors (remittances and transfers of accumulated savings as foreign investment); and collective or individual remittances aimed at furthering social and economic community development. (Stocchiero, 2004, p. 16). They can take different forms, as shown in Table 1. 
A study of migrant-sending households in Serbia-Montenegro receiving remittances from Switzerland, confirms that in most of the cases, due to the lack of trust in financial institutions, as well as high transfer cost and inconvenience, remittances are sent informally (IOM, 2006). Only about 10\% of the surveyed population preferred formal transfers through banks, while transfers through private money transfer organizations such as Western Union were not identified.

Remittances were generally used to support basic family needs and living costs, while remittances used as investment were mostly channeled towards housing and/or agricultural activities, with a small proportion (8\% of respondents) investing remittances in entrepreneurial endeavors. It was reported that remittances had great impact of poverty alleviation and in many families they enabled people to buy houses that they could not otherwise afford. Remittances helped some people to afford medical care and medicines and in a smaller number of cases (11\%) to pay for children's education.

The authors concluded that the use of remittances was influenced by four main factors: (1) socio-demographic profile of the recipient household, (2) the economic milieu in which remittances are received, (3) recipient's familiarity with and interest for investment opportunities, and (4) people's attitudes towards and access to financial services.

Although remittances are an important poverty reduction tool and interest of diaspora members in the economic future of their motherland is a noble goal, there is a danger, as Elton (2006, p. 3), from the MIT Center for International Studies claims, that »they are becoming a smokescreen to hide the pressing need to address the structural causes of unemployment and poverty in migrant sending nations" as well as to »to hide the negative effects of the neoliberal reforms". Some other researchers and scholars share her skepticism and pessimism about remittances (Table 2). 
Table 2: Pessimistic and optimistic perspectives on remittances

\begin{tabular}{|l|l|}
\hline $\begin{array}{l}\text { Fears Regarding Remittances } \\
\text { (Stahl \& Arnold, 1986) }\end{array}$ & Optimism Regarding Remittances \\
\hline $\begin{array}{l}\text { Remittances do not lead } \\
\text { to productive investments } \\
\text { but instead fuel profligate } \\
\text { consumption. }\end{array}$ & $\begin{array}{l}\text { Micro-level: non-productive investments and } \\
\text { consumption improves standard of living and quality } \\
\text { of life (Stahl \& Arnold 1986). Can tide people over in } \\
\text { times of crisis (Van Hear, cited in Østergaard-Nielsen } \\
\text { 2003b) and help diversify household risks. Macro-level: } \\
\text { consumption increases demand, producing multiplier } \\
\text { effects that stimulate home-country industries and } \\
\text { economies (Stahl \& Arnold, 1986). }\end{array}$ \\
\hline $\begin{array}{l}\text { Distribution of remittances is } \\
\text { uneven and increases income }\end{array}$ & $\begin{array}{l}\text { Remittance income is more evenly distributed than } \\
\text { both overseas development aid and foreign direct } \\
\text { investment (Hugo, 2003). }\end{array}$ \\
\hline $\begin{array}{l}\text { Remittance expenditures may } \\
\text { result in inflation. }\end{array}$ & $\begin{array}{l}\text { Price gains are mitigated by the allocation of resources } \\
\text { to production of higher-priced goods (Stahl \& Arnold, } \\
\text { 1986). }\end{array}$ \\
\hline $\begin{array}{l}\text { Remittances may increase } \\
\text { dependency with the risk of } \\
\text { sudden decline. }\end{array}$ & $\begin{array}{l}\text { Labor export should be seen as any other export } \\
\text { sector which must be carefully managed to avoid } \\
\text { dependence (Keely \& Tran, 1989). }\end{array}$ \\
\hline $\begin{array}{l}\text { Remittances adversely affect } \\
\text { agricultural development } \\
\text { by removing incentives to } \\
\text { laborers. }\end{array}$ & $\begin{array}{l}\text { Decline in agricultural productivity is due to loss of } \\
\text { labor power through emigration, not complacency } \\
\text { amongst workers (Stahl \& Arnold, 1986). }\end{array}$ \\
\hline
\end{tabular}

Source: Gamlen, (2006 p. 14)

\subsection{Diaspora as a foreign investor: partnership through serbian regional chambers of commerce}

As previously stated, the end users of remittances use them for consumption purposes and hence the money is not invested in sustainable development of the recipient state. Besides monetary remittances and community development support, recognized as foreign investors, diaspora members can make significant contributions to the development of the countries of origin. A model, proposed by Filipovic (2007), which calls for the establishment of regional diasporic centers within each of the 17 regional chambers of commerce in Serbia, was used as the basis for a joint project initiated by the Ministry of Diaspora and the Serbian Chamber of Commerce System. The project, launched in the year 2007, was envisioned to enable partnership between the state and its diaspora on both local and regional levels. In addition to general goals of fostering development with the involvement of the diaspora, as well as the reduction in unemployment and poverty, channeling of remittances through legal institutions for investing in Serbia's businesses and informing the diaspora of business opportunities that the Republic of Serbia has to offer on both regional and local levels the project had a number of specific goals:

- To provide assistance for investors from the diaspora towards their integration into the economy of the Republic of Serbia.

- To provide diaspora with incentives to invest in Serbia (offering preferential interest rates, the »matching fund « programmes such as 
the Mexican Tres Por Uno (for each dollar that comes from diaspora, government invests three dollars), foreign-currency-denominated bonds to expatriates...).

- To provide technical assistance and guide through bureaucratic procedures.

- To help mitigate corruption related to diaspora investments.

- To ease diaspora entrepreneurs access to credits in Serbia.

- Affirmation of successful examples of businesses in the aforementioned cases.

- Motivation of potential partners from the diaspora through affirmation of the already existing and successful examples.

- Recognition of the possible problems that investors from the diaspora may face and their identification for policy improvement.

- To provide assistance for investors from the diaspora towards their introduction to good world practice (education, quality, design, packaging, marketing, etc.).

- Creation of an information database containing: (i) information pertinent to the business diaspora, (ii) submitted business proposals - from the local and regional levels - and from the diaspora, with the goal to create partnership between the two and (iii) already established businesses with capital from diaspora.

- Creation of a positive picture towards the economic partnership potentials between Serbia and its diaspora.

\section{Conclusion}

The development of diaspora strategies is essential because it demonstrates how state agencies, policy makers and individual citizens themselves have begun to think beyond national borders and make efforts to build nonterritorial forms of organisation, such as Diaspora Virtual University. Promotion of networks, strategic alliances and sustained institutional cooperation between the diaspora and the policy makers such as the Ministries for Diaspora, as well as other officials dealing with diaspora and development related issues have become the subject of primary interest in many countries, one of them being Serbia.

The role of the government, contrary to the actions of many administrations, including Serbian, should not be to manage their diasporas, but to promote public policy making which is sensitive to the needs and aspiration of the members of diaspora and their counterparts in the motherland, nurture ties with and within diaspora and especially establish managerial practices directed at creating appropriate environment and providing necessary resources (enabling conditions) for the promotion of diaspora-motherland partnership. 
As a part of the effort to formulate effective and just policies used to respond to the brain drain, the paper analyses and recommends different policy types. Among different models of academic diaspora congregation is, no doubt, the alumni model, which proved to be very useful for both, developed and developing countries. The paper presents the concept as a part of the »brain gain « model and states the principles distilled from the alumni concept experience, which summarize the current wisdom regarding development of a community which will serve as the »intelligence pook for Diaspora Virtual University.

Different types of remittances, as well as pessimistic and optimistic perspectives on remittances, are analyzed in the paper, and recommendations are summarized for current and future policy makers. Recognizing diaspora as a valuable foreign investor a model of partnership through the Serbian Regional Chambers of Commerce is also proposed.

Jovan Filipovic, PhD, is a Quality management professor and the Vice-Dean for Quality and International Cooperation at Belgrade University Faculty of Organizational Sciences. He earned his PhD and MSME from Purdue University (USA) School of Mechanical Engineering and BSME from Belgrade University School of Mechanical Engineering. He also earned his PhD from the University of Ljubljana Faculty of Public Administration, defending his thesis entitled: "Management of the Serbian Diaspora Virtual Organization as a Complex Organization «. He is the Executive director of GEPS, an organization dedicated to networking Serbian experts in the world and the author of several books and papers published in international and Serbian journals.

Srečko Devjak, PhD, is a Full Professor at the Faculty of Administration for the field of quantitative analyses for administration support. He obtained a BSC in Mathematics, an MSc in Operation Research and a PhD in Information and Management Sciences in 1987 at the Faculty of Economics at the University of Ljubljana. From 1975 to 1992, he worked as a consultant for the field of business economics and organisation development in leading Slovenian consulting institutes. He has been regularly employed at the University of Ljubljana since 1992. From 1998 to 2005, he was Vice-Dean for Study and Student Affairs and from 2005 to 2009 he held the post of Dean at the Faculty of Administration. His research includes methods for the optimisation of operation of various organizational systems. Within his research, he developed and applied special models, such as Forest Balance in Slovenia, Budget Indicators of Municipalities and Indicators of Investment Efficiency in Health Care. He regularly presents the results of research in lectures at foreign universities and articles in relevant international publications. 
Bogomil Ferfila, PhD is full professor at the Faculty of Social Sciences, University of Ljubljana, where he teaches courses in Comparative Politics, Area Studies and Public Economics. He has degrees in economics, political science and sociology from different universities. Professor Ferfila has authored more than 30 books which were published in Slovenia, USA, USSR, Canada, Serbia, India and Germany. He has authored numerous articles and shorter works, some of them published in Canadian, French, Polish, Japanese, American magazines. Professor Ferfila has had lectures at universities all over the world, from USA to China. He also participated in seminars and conferences in many countries. 


\section{References}

- BGM, Brain Gain Malaysia, 2010. Malaysian Science and Technology Information Centre, www.mastic.gov.my

- Boyle, M. \& Kitchin, R. (2008). Towards an Irish Diaspora Strategy: A Position Paper. NIRSA Working Paper Series, no. 37.

- Boyle, M., Kitchin, R. \& Ancien, D. (2009). The NIRSA Diaspora Strategy Wheel and Ten Principles of Good Practice. http://www.nuim.ie/nirsa/Diaspora/

- Connell J.\&Brown R. (2004). The Remittances of Migrant Tongan and Samoan Nurses from Australia. Human Resources for Health 2(2), 1-21.

- De Wit, B. (2004). Methodology of Boundary Work at the interface of Science, Policy and Society: Basis for a Manual. Den Haag.

- Dearing, J. W. \& Rogers, E. M. (1996). Agenda-Setting (Communication Concepts). Sage Publications.

- Elton, C. (2006). Remittances: Latin America's Faulty Lifeline. MIT Center for International Studies Audit of the Conventional Wisdom, 2006(04).

- Filipovic, J. (2007). Economic Partnership with the Diaspora at the Regional and Local Levels. Donor Sectoral Meeting - Ministry for Diaspora. http:// happytreeflash.com/ministry-for-Diaspora-ppt.html

- Filipovic. J.\& Putnik, G. (2010). Serbian Diaspora Virtual University: Human Resource Potential. Public Administration Role in Social and Economic Transformation in Sout-East Europe. University of Ljubljana.

- Fischhoff. B., Lichtenstein, S., Slovic, P., Darley. S. \& Keeney. R. L. (1981). Acceptable Risk. New York: Cambridge University Press.

- Gamlen, A. (2006). Diaspora Engagement Policies: What are they, and what Kinds of States use them? Centre on Migration, Policy and Society, WP2006(32), $1-3$.

- Hugo, G. (2003). Migration and Development: A Perspective from Asia. International Organization for Migration Research Series, no. 14.

- Ionescu, D. (2006). Engaging Diasporas as Development Partners for Home and Destination Countries: Challenges for Policymakers. Geneva, Switzerland: International Organization for Migration.

- Keely, C. B. \& Tran, B., N. (1989). Remittances from Labor Migration: Evaluations, Performance, and Implications. International Migration Review 23(3), 500-525.

- Kilpatrick, D. (2000). Definitions of Public Policy and Law. http://www.musc. edu/vawprevention/policy/definition.shtml/

- Kingdon, J. W. (1995). Agendas, alternatives, and public policies (2nd ed.). New York: Longman.

- Kunreuther, H. (1981). Risk: a Seminar Series. (IIASA Collaborative Proceedings Series) Laxenburg, Austria: International Institute for Applied Systems Analysis.

- Lowell, L. B. (2001). Policy Responses to the International Mobility of Skilled Labour. International Migration Papers 45 (December). Geneva: International Migration Branch.

- Meyer, J-B. \& Brown, M. (1999). Scientific Diasporas: A New Approach to the Brain Drain Management of Social Transformations - MOST. Discussion Paper No. 41, Prepared for World Conference on Science UNESCO-ICSU, Budapest. http://www.unesco.org/most/meyer.htm 
- Mitra, S., Andrew, D., Gyulumyan, G., Kaminski, B., Kuznetsov, Y. \& Vashakmadze, E. (2007). The Caucasian Tiger: Sustaining Economic Growth in Armenia. World Bank Publications.

- National Consumer Council (2004). Making Public Services Personal: A New Compact for Public Services. London: NCC.

- Østergaard-Nielsen, E. (2003). International Migration and Sending Countries: Key Issues and Themes. In: Østergaard-Nielsen, E. (Ed.). International Migration and Sending Countries: Perceptions, Policies and Transnational Relations (3-32). Basingstoke: Palgrave Macmillan.

- Puentes-Markides, C. (2007). Policy Analysis and Decision Making, Bridgetown, Barbados, October 15-17. http://www.paho.org/english/ad/dpc/nc/cmn-pobar-7-4-pol-agenda.pdf

- Roberts, B. (2004). Remittances in Armenia: Size, Impacts and Measures to Enhance Their Contribution to Development, Bearing Point (under contract to USAID).

- Stahl, C. W., and Arnold, F. (1986). Overseas Workers' Remittances in Asian Development. International Migration Review 20(4), 899-925.

- Stocchiero, A. (2004). Fostering Egyptian Local Development Through Diasporic Networks in Italy. CeSPI Policy Paper on The Integrated Migration Information System (IMIS). Rome, Italy.

- Van Hear, N. (1998). New Diasporas: The Mass Exodus, Dispersal and Regrouping of Migrant Communities (195-231). London: UCL Press.

- Woldetensae, Y. (2007). Optimizing the African Brain Drain: Strategies for Mobilizing the Intellectual Diaspora towards Brain-Gain. Paper presented at the Conference of Rectors, Vice Chancellors and Presidents of African Universities (COREVIP) in Tripoli, Libya. 
POVZETEK

\section{STRATEGIJE IN POLITIKE ANGAŽIRANJA DIASPORE}

Ključne besede: politike angažiranja diaspore, beg možganov, pridobitev možganov, nakazila, študentski model, naložbe v diasporo

Diaspore že dolgo prispevajo k svojim domovinam, ne da bi čakale, da jih v ta namen združijo različne politike, ki povedano po resnici, pogosto pomenijo glavno oviro vzpostavitvi partnerstva. Vseeno pa je partnerstvo med diasporo in domovino tesno povezano z institucionalnimi okviri, s socialno-ekonomskimi okoliščinami, političnim miljejem in z vprašanji zaznavanja, podob, zaupanja ter družbene identifikacije, tako v domači državi kot v državi gostiteljici, večina teh pa spada v okvir javne uprave. Poleg tega sta v nekaterih državah naraščanje ozaveščenosti o politiki in poglobljeno razumevanje povezave med diasporo in razvojem posledici prizadevanj javne uprave.

Da bi maksimirali koristi potencialnega partnerstva med diasporo in domovino ter zagotovili, da se diasporam ne odreka lastništva njihovih prispevkov, bi morale biti politike, ki jih številne države vedno bolj razvijajo in s katerimi želijo diaspore izkoristiti, zbrati skupaj in mobilizirati, realistične, dobro zasnovane, pravične ter izvedljive. Znotraj diaspore se nahaja dragocen intelektualni, družbeni in finančni kapital, ki ga morajo države pošiljateljice poiskati ter spodbujati preko mrež in zavezništev (»verige možganov«). Mobilizacija tega latentnega »naravnega« vira, kot ga imenuje Gamlen (2006), s pomočjo takšnih povezovalnih programov ne zahteva velike naložbe v infrastrukturo, kar je prednost katere koli možnosti diaspore. Na tem mestu možnost diaspore pomeni eno od dveh alternativ pridobitve možganov. Kot navajata Meyer in Brown (1999), se pridobitev možganov lahko doseže s pobudami za vrnitev diaspore domov (možnost povratka) ali pa z njeno mobilizacijo na daljavo in zavezanostjo k razvoju domovine (možnost diaspore). Predpostavka, da se veliko število izseljencev najverjetneje ne želi vrniti, vsaj ne na kratki rok, je podlaga za precejšnje število politik do diaspore.

Razvoj strategij diaspore je bistvenega pomena, saj kaže, kako so državne agencije, oblikovalci politike in posamezni državljani začeli razmišljati onkraj državnih meja in kako si prizadevajo ustvariti neteritorialne oblike organizacij, kot je Virtualna univerza Diaspore. Promocija mrež, strateških zavezništev in trajnostnega institucionalnega sodelovanja med diasporo in oblikovalci politike, kot je Ministrstvo za diasporo in drugi uradniki, ki se ukvarjajo z diasporo ter vprašanji razvoja, je postala predmet poglavitnega interesa v mnogih državah, med katerimi je tudi Srbija.

V poskusu, da bi prišli do »široko zasnovane in moralno osnovane strategije» kot tudi do »krovne politike in povezanih praks, ki lajšajo tekoči razvoj odnosa 
med (domovino) in njeno diasporo«, pričujoče delo najprej pojasni pomen strategij, politik, predvsem javnih politik, in praks.

Z uporabo enake tipologije, kot jo je uporabil Gamlen pri pregledu politik angažiranja diaspor v več kot 70 državah, je v članku analiziran primer Srbije. Da bi postavili temelje za razvoj politike, smo analizirali tudi model določanja programa in ga združili s priročnim orodjem za oblikovalce politike, ki trenutno oblikujejo in izvajajo politike diaspore.

Kot del prizadevanja, da bi oblikovali učinkovite in pravične politike, s katerimi bi se odzvali na beg možganov, so v članku analizirane in priporočene različne vrste politik. Med različnimi modeli akademskega združevanja diaspor je brez dvoma študentski model, ki se je izkazal kot zelo koristen tako v primeru razvitih držav kot v primeru držav v razvoju. Članek predstavi ta koncept kot del modela "pridobitve možganov« in navaja načela, izpeljana iz izkušnje študentskega koncepta, ki povzemajo trenutno védenje o razvoju skupnosti, ki bo služila kot »inteligenčni sklad« za Virtualno univerzo Diaspore. Delo analizira različne vrste nakazil, vključno s pesimističnimi in optimističnimi vidiki nakazil, povzeta pa so tudi priporočila za trenutne ter bodoče oblikovalce politike. Ob zavedanju, da je diaspora dragocen tuj investitor, je predlagan tudi model partnerstva prek srbskih območnih gospodarskih zbornic.

V nasprotju z delovanjem številnih administracij pa vloga vlade, tako tudi srbskje vlade, ne bi smela biti obvladovanje diaspor, temveč spodbujanje oblikovanja javne politike, ki bi upoštevala potrebe in želje pripadnikov diaspor ter njihovih ekvivalentov v domovini, negovanje vezi z diasporo in znotraj nje ter predvsem vzpostavljanje menedžerskih praks, ki bi se usmerjale k oblikovanju ustreznega okolja in zagotavljanju nujnih virov, omogočanju pogojev za promocijo partnerstva med diasporo in domovino. 